\title{
Er friluftsliv meningsløst \\ Giver det mening at skelne det fra sport?
}

Af Kenneth R. Olwig

Er det meningsløst at dyrke friluftsliv? Dette kan opfattes som et provokerende spørgsmål, hvor det provokerende ligger i en antydning af, at det er muligt, at mange mennesker udøver, forsker i og forvalter noget, der er uden mening. Hvis der ikke er nogen mening med friluftslivet, er det meningsløst at dyrke det, forske i det og forvalte det. De fleste vil derfor reagere på dette spørgsmål med at svare, at friluftsliv selvfølgelig ikke er meningsløst. Alligevel vil jeg påstå, at man godt kan stille spørgsmålstegn ved, om mange af dem, der forsker i eller forvalter friluftsliv, ikke reelt behandler friluftslivet som noget, der er meningsløst. Mening betyder »det, som en person under en handling eller ytring har $\mathrm{i}$ tanker, i sinde ... det bevidsthedsindhold, en person $\emptyset$ nsker at give udtryk for ved en ytring. « Hvor ofte betragtes friluftsliv, som et udtryk for et »bevidsthedsindhold « eller som en »ytring «? Hvis ikke dette er tilfældet, opfattes friluftsliv så som noget, der i ordets egentlige betydning er »menings$1 \varnothing s t \ll$ ?

Jeg tror, at det kan være fristende for forskere og forvaltere at betragte friluftsliv ud fra f.eks. »behaviorismens « eller »adfærdsforskningens « normer, hvor friluftsliv defineres som en form for adfærd, dvs. noget »objektivt«, som man derefter kan måle og tælle, klassificere og kategorisere. Dette er forståeligt, i og med at både videnskabsmænd og forvaltere $\varnothing$ nsker at være »objektive«. Problemet er bare, at »me- ning « handler om det subjektive, snarere end om »objektiv viden. $\ll^{1}$ Hvis friluftsliv har mening, er det vigtigt at se adfærd i forhold til bevidsthedsindhold - dvs. som en ytring - selv der, hvor det umiddelbart kan være svært at se, hvad dette indhold skulle være. I det følgende vil jeg derfor forsøge at sige noget om meningen med friluftsliv ved at skelne det fra sport. Mening opstår nemlig i den proces, hvorved vi skelner ting fra hinanden og giver dem navn. Sådan skaber vi os en meningsfyldt verden, præcis ligesom Gud efter sigende skulle have skabt selve verdenen i sin tid.

\section{Friluftsliv og sport}

Fra et objektivt synspunkt ligner friluftsliv ofte sport til forveksling. ${ }^{2}$ En person, der $\emptyset$ ver sig i en olympisk disciplin inden for sejl- eller skisport kan være svær at skelne fra en, der driver friluftsliv i båd eller på ski. En mand, der går friluftstur med en stok, kan på afstand være vanskelig at skelne fra en person, der går med en golfkølle. I nogle tilfælde kan det være svært at skelne selve golfbanen fra et naturlandskab det er f.eks. tilfældet i St. Andrews, Scotland, hvor golfbanen ligner en strandeng. Og de mennesker, der udøver sport og har et aktivt friluftsliv får vel nogenlunde det samme ud af de to fritidsaktiviteter målt $i$ energiforbrug, opøvning af muskelkraft $m . v$. Alligevel mener jeg, at der er mening $\mathrm{i}$ at skelne mellem disse to former for aktivi- 
teter, og at denne mening har praktiske konsekvenser ikke mindst for forskning og naturforvaltning.

En væsentlig skelnen mellem friluftsliv og sport er, at friluftsliv er forbundet med »naturen«, mens sport ikke er det. Det er således normalt ligegyldigt, om en sport drives indendøre eller udendøre, eller om den drives på kunststof eller naturstof (f.eks. i tilfældet græs). Det er mest et praktisk spørgsmål. Friluftsliv kan derimod næppe drives indendøre, og det forbindes ofte med et liv i naturen. Det er således almindeligt i Norden, at friluftsliv forvaltes $\mathrm{i}$ forbindelse med naturforvaltningen. ${ }^{3}$ Man freder naturen eller opretter naturparker bl.a. af hensyn til friluftsliv. Sport lukkes derimod ofte ude af naturen. Golfbaner er ikke populære hos naturforvaltere, i hvert fald ikke mens de er på arbejde.

\section{Friluftsliv og natur}

Jeg skal her opstille en hypotese til at forklare forskellen mellem friluftsliv og sport. Den kan måske være brugbar for dem, der som forskere eller forvaltere beskæftiger sig med friluftsliv, fordi den forsøger at forklare meningen med friluftsliv.

I »natursamfund « hænger de fleste aktiviteter, som vi i dag kalder sport, sammen i en bestemt livsform. Samlere og jægere løber, kaster med kugler, med spyd, ror eller står på ski som en naturlig del af hverdagen og en livsproces, der har til formål at skaffe bytte. De skelner ikke synderligt mellem arbejde og fritid. Handlinger, som vi vil betegne som leg, kunst eller religion, er nært relateret til jagten. Det karakteristiske ved vores samfunds historie er, at det involverer en stigende arbejdsdeling og specialisering. Bonden har således et mere ensformigt arbejde, hvor han måske i time- vis træller bag en plov i omgivelser, som han selv har gjort mere ensformige af hensyn til landbrugsproduktionen.

Det er almindeligt, at man definerer natur som »menneskets oprindelige eller naturlige tilstand « og som en »beskaffenhed eller tilstand af en vis oprindelig, primitiv art, uden (overdreven) forfinelse, arbejdsspecialisering, fremskreden teknisk udvikling osv.« Der er samtidig en klar forbindelse mellem denne opfattelse af naturen og definitionen af den fysiske natur som »den mennesket omgivende ydre verden, betragtet som den verden, i hvilken menneskene færdes under aaben himmel ...; den umiddelbart synlige del af jordoverfladen med dens forskellige bestanddele (kløfter og bakker, søer og floder osv.) og tilhørende ydre- og planteverden, saaledes som den ses henliggende under aaben himmel og i nogen grad overladt til sig selv. $\ll^{4}$ Det, der tilsynladende sker, når mennesker holder op med at være »naturlige, « er, at deres omgivelser holder op med at være natur.

En betydning af begrebet »mening « henviser til, hvad der fortolkes som intention, hensigt eller endemål. En karakteristik ved »natursamfundet « er, at det er nemt at se meningen i det, man gør. Der er en sammenhæng mellem alle de handlinger, man udfører for at gennemføre jagten, også når man ikke er på selve jagten (f.eks. i ritualer eller når børn og voksne leger, at de er på jagt). Efterhånden som samfundet bliver opsplittet og specialiseret, bliver det sværere at se meningen i det, man gør, i denne betydning af begrebet, dvs. i forhold til grundliggende endemål med livet. At søge tilbage til en mere »naturlig « livsform repræsenterer således også en søgen efter en mere meningsfyldt tilværelse. En tilværelse, hvor man bedre kan se sammenhængen mellem f.eks. ens daglige gøremål, maden man spiser, klæderne man går i, osv. 
I mange samfund er der en forestilling om, at livet i naturen er bedre og mere $»$ naturligt «, ja nærmest paradisisk. Det kan virke som det rene sværmeri, når man tænker på mange af de materielle goder, som civilisationen har givet os. Men sagen er ikke helt så enkel. Antropologer har således betegnet samler- og jægersamfund som de oprindelige overflodssamfund, fordi jægerog samlertilværelsen kræver en relativt kort koncentreret arbejdsindsats. ${ }^{5}$ Denne livsforms mange immaterielle goder har da også betydet, at folk som regel kun har villet opgive den under tvang. Men livsformen har det problem, at den ikke skaber ret meget materielt overskud, der kan bruges af andre. Derfor har man brugt (og bruger stadig) forskellige metoder til at tvinge folk ind i livsformer, der producerer overskud f.eks. ved at udnytte ressourcerne mere intensivt. Ved at beskatte folk, der driver forskellige former for subsistensbrug, hvor samleraktiviteter og jagt ofte indgår, kan man således tvinge dem til at udnytte deres omgivelser gennem et mere intensivt agerbrug, så de kan producere et overskud, der gør det muligt for dem at betale skat. Der kan derfor være gode historiske grunde til, at folk har set tilbage på naturlivet med en vis nostalgi, og at de har tillagt dette liv en særlig betydning som et mere naturligt liv.

\section{Sport og natur}

Sport har både i fortid og nutid været et vigtigt middel til at tvinge folk ud af mere »primitive« livsformer, der udnytter miljøgrundlaget ekstensivt. Når jagt er blevet defineret som sport, bliver den jagt, som folk før drev for at ernære sig, omdefineret til krybskytteri. ${ }^{6}$ Jagtsport og de arealer, der egner sig til jagt, bliver derved reserveret for dem, der har råd til at jage ikke for at ernære sig, men for »sportens « eller »adspredelsens« skyld. Men sport er også forbundet med en moral, som retfærdiggør sportsud $\varnothing v e r e n s$ handlinger og ford $\varnothing \mathrm{mmer}$ ikke sportslige handlinger - svær straf, inklusive dødsstraf, har således i tidligere tider været en lovlig straf for krybskytteri. En »gentleman« er en »good sport «, og samtidig en, der ikke arbejder (»one whose means enable him to live in easy circumstances without engaging in trade, a man of money and leisure «). ${ }^{7}$ Meget forenklet kan man sige, at en gentleman lever af det overskud, der bliver skabt, når andre tvinges ind i mere specialiserede erhverv f.eks. ved at deres subsistensjagt bliver omdannet til krybskytteri. Magt og position manifesteres gennem mulighederne for at råde over fritid.

Efterhånden som samfund er blevet mere økonomisk og socialt opdelte, er sportificeringen af samfundslivet blevet mere markant. Da roning blev omdannet til en sport, blev de, der arbejdede med at ro, udelukket fra at deltage i denne sportsgren. Vi har ganske fornylig set en udvikling i Danmark, hvorved cyklen i stigende grad er blevet omdefineret fra at være en transportform, især for dem der ikke har råd til bil og bus, til at være en form for sport for dem, der netop har råd til andet. Det er »in« i de bedre kredse at køre med højt specialiserede og upraktiske cykler på biltaget hen til særlige steder, der er reserveret til fritidscykling. Sport er ikke længere direkte forbudt for visse dele af befolkningen, som jagt på dyr blev det tidligere, men er i stedet forbundet med sociale mekanismer, der tjener til at markere sportsudøvernes privilegerede position.

Sport forbindes også med en slags moral, der understøtter den gældende samfundsorden. Olympiadens motto, »hurtigere, højere og stærkere, « og den dermed for- 
bundne elitisme, er nært beslægtet med industrisamfundets målsætninger. De monotone, stærkt specialiserede bevægelser på regulerede baner, som karakteriserer mange sportsgrene, passer også til industrisamfundets idealer angående målbarhed, præstation og orden. Hele samfund kappes nu om den prestige, der ligger i at have råd til at give folk så meget fritid, at de kan konkurrere i højt specialiserede sportsgrene. ${ }^{8}$

\section{Friluftsliv, natur og sport}

Friluftsliv adskiller sig fra sport på en række punkter. Der er ingen formaliseret konkurrence, og der er derfor heller ingen behov for baner, der forenkler miljøet af hensyn til målbarhed og konkurrence. ${ }^{9}$ Tværtimod forbindes friluftsliv, som sagt, med naturen, og dermed med miljøer som ikke er blevet forenklet af civilisationen. Der er

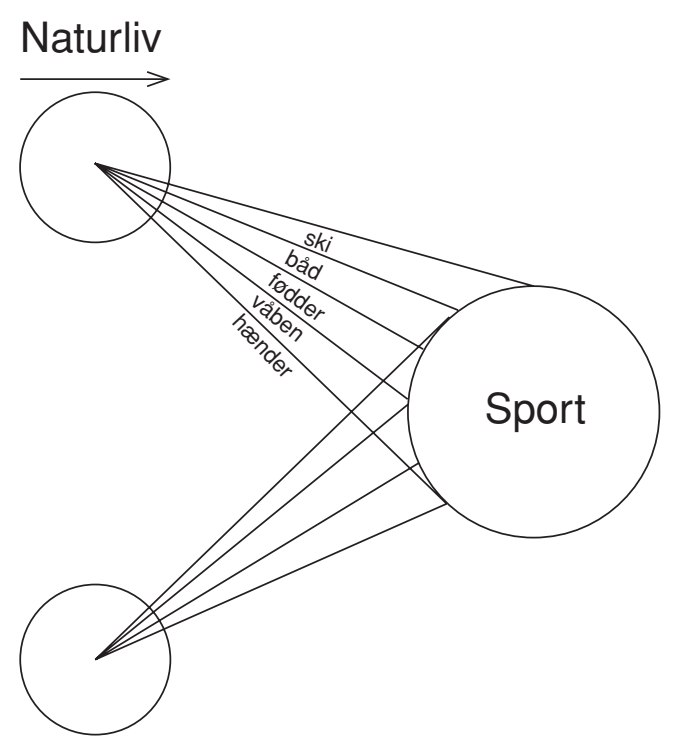

Friluftsliv

Tegningen viser i meget grove trak den $\mathrm{ci}$ vilisatoriske udvikling, der kommer til udtryk $i$ henholdsvis sport og friluftsliv. heller ikke tale om en elitisme, der har til hensigt at udelukke jævne folk. Naturen opfattes netop i en del nordisk lovgivning som allemandseje, der gerne skulle være tilgængelig for alle. ${ }^{10}$ Naturlovgivningen modvirker sportens tendens til at ville lukke ikke-privilegerede folk ude - hvad enten det drejer sig om jagt eller golf. Endelig er det karakteristisk for mange former for friluftsliv, at der indgår en række sammenhængende fysiske handlinger, der giver (frilufts)livet mening i den forstand, at livsformålene bliver overskuelige. En kanotur kan således godt involvere padling, bevægelser til fods, fiskeri, samlingen af bær og svampe, osv. En friluftstur af denne art minder således ikke så lidt om samlerens og jægerens livsform. Forskellen er bare den lange udviklingshistorie, der ligger mellem friluftslivsud $\varnothing$ veren og samlerne og jægerne. Friluftslivet forudsætter et samfund, der er blevet tilstrækkeligt specialiseret og opslittet, således at folk bevidst eller ubevidst kan søge tilbage til en natur, som samfundet som helhed har forladt.

\section{Friluftsliv og mening}

Ifølge denne argumentation har friluftsliv mening i den basale forstand, at livets endemål bliver overskuelige på en sådan måde, at man kan se en sammenhængende mening i, hvordan ens gøremål bidrager til at opretholde livet. Men i og med at friluftslivet ikke er lig med samlerens og jægerens livsform, men indebærer overlagte handlinger, der bringer en væk fra en civiliseret dagligdag og ind i naturen, kan der også være tale om en vis refleksion over meningen med denne handling. Det vil sige, at friluftsliv også kan have mening på symbolplanet, idet udøvning af friluftsliv kan være en måde, hvorpå man udtrykker en mening. Sædvanligvis vil det være 


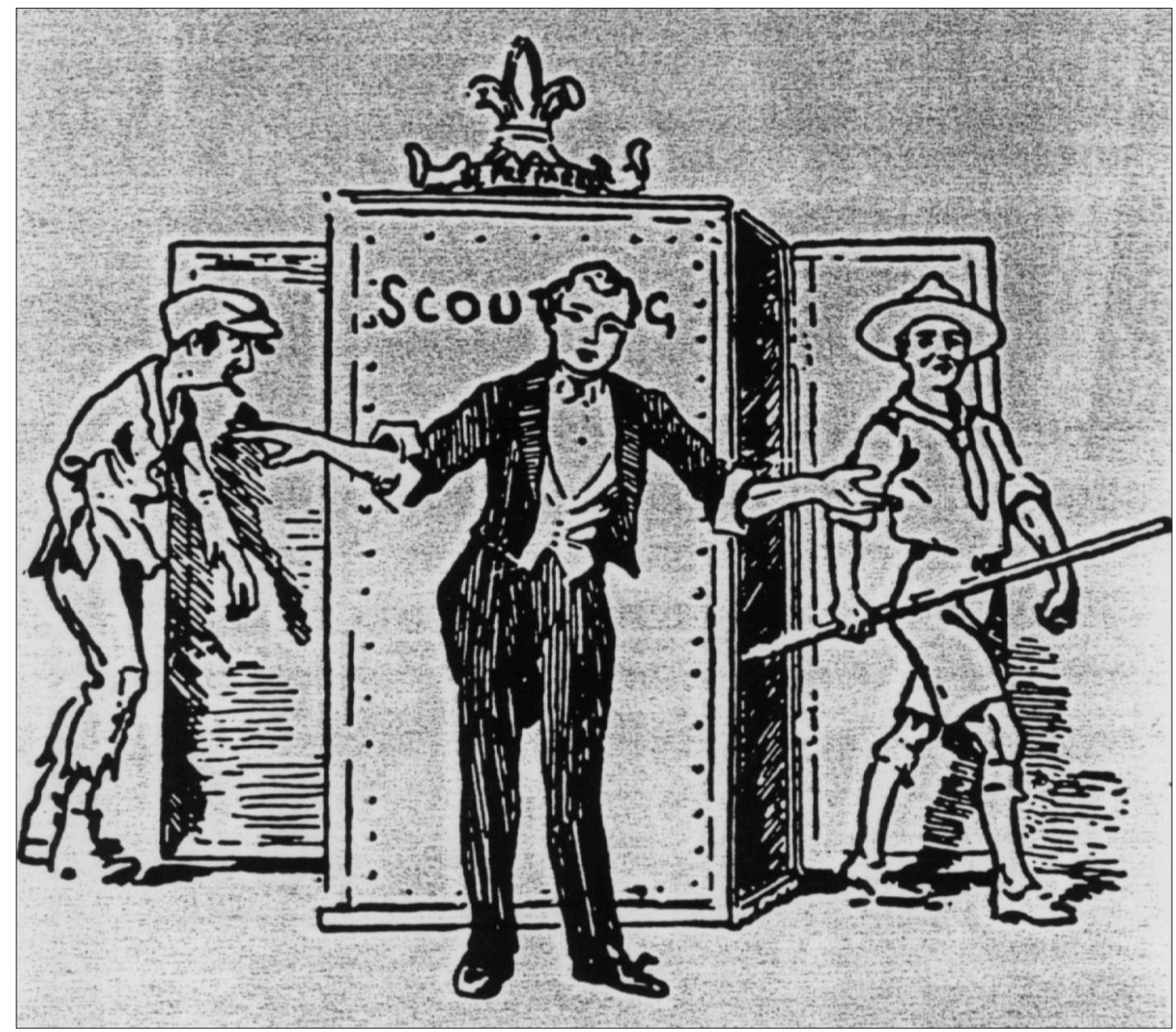

Lord Robert Baden-Powell, den engelske grundlagger af spejderbevagelsen, har tegnet dette billede, som han kaldte spejderførerens »store nummer.«

et udtryk for en holdning til civilisationsprocessen. Det er f.eks. helt klart meningen med den tradition for friluftsliv, som har sit udspring i Henry David Thoreaus arbejde, eller i den del af spejderbevægelsen, der har hentet sin inspiration hos Ernest Thompson Seton. ${ }^{11}$ Disse forfattere udtrykker klart deres holdning til friluftsliv i ord. Men fordi symbolikken i friluftsliv ligger primært på det kropslige plan, i en fysisk handling, kan meningsudsagnet være svært at tolke på en entydig måde. Der kan ovenikøbet være tale om meningsudtryk, som friluftslivsudøveren kun er lidet bevidst om. Nogle kan f.eks. være meget bevidste om betydningen af at bruge udstyr og tøj lavet af naturmaterialer. Andre køber måske deres tøj i en butik som Naturkompagniet, fordi de har en vag fornemmelse (skabt af reklamebranchens symbolik) af, at det skulle være godt med natur. $\mathrm{Og}$ så er der også nogle, som ikke lægger nogen værdier i de materialer, de bruger til friluftsliv. ${ }^{12}$

De skjulte og bevidste meninger, der kan ligge i friluftslivet, forstået som ytring, 
kan skabe konflikter mellem forskellige typer af friluftslivsudøvere og mellem friluftslivsudøvere og sportsfolk. Der kan således være konflikter mellem friluftslivsudøvere, der kræver forskellige grader af naturlighed i de faciliteter, som stilles til rådighed for friluftslivet. Samtidig vil de fleste friluftslivsudøvere se skævt til de anlæg, som sportsfolk kræver. Fordi friluftsliv først opstår, når en bestemt samfundsgruppe har været igennem en moderniseringsproces, vil friluftslivets $\gg$ tilbageskuende« tendens ligeledes ofte medføre spændinger i forhold til dem, der bruger moderne redskaber så som snescootere. Sådanne konflikter er måske mest præget af uoverensstemmelser på det symbolske end på det praktiske plan. Det at anvende snescootere eller motorbåde kan være mest generende p.g.a. den symbolske betydning, de har, snarere end p.g.a. den egentlige for-

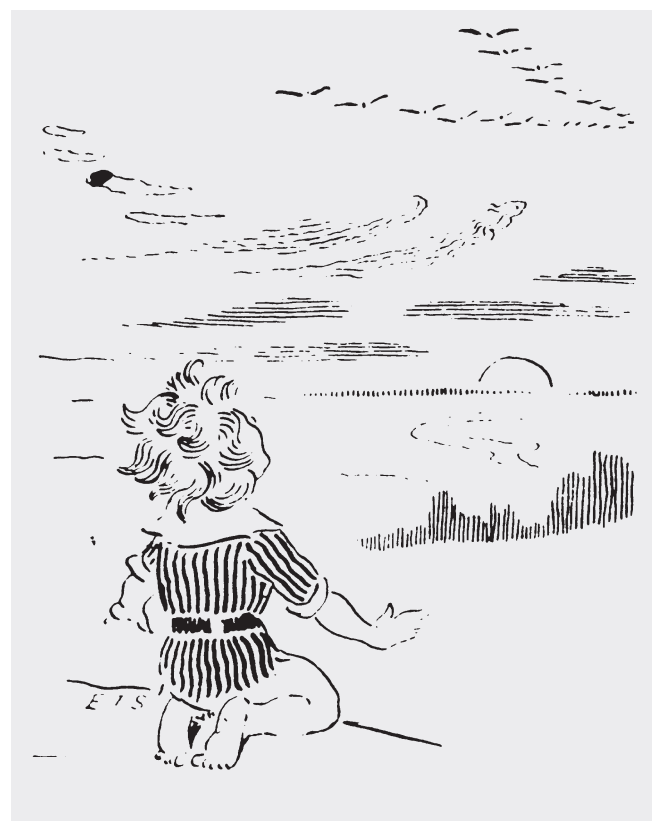

Fra E. Thompson Setons bog om Woodcraft-bevagelsen (20. udgave, 1925), en forldber for spejderbevagelsen. styrrelse, de forårsager. Disse modsætningsforhold skaber selvfølgelig problemer for dem, der skal forvalte naturen og friluftslivet, også fordi de i deres privatliv kan være part i sagen uden at være klar over det. Meningen med friluftsliv er en besværlig sag, og det er forståeligt, hvis nogle vælger at se bort fra den fremfor at forsøge at forstå den.

Selv om sport og friluftsliv i mange henseender er lette at adskille fra hinanden, findes der også former for sport, der kan ses at have antaget friluftslivets former. I dette sportificerede friluftsliv møder vi en del af de træk, der kendetegner sport, så som konkurrence, elitisme og overvindelsestrang (hurtigere, højere, stærkere). Dette kendes indenfor fjeldklatring, overlevelsesture i vildmarken, kanindræberkurser. I forbindelse med elitismen kan tendensen til at ville ekskludere andre også opstå. Det er ikke mindst i konflikterne med ægte »naturfolk«, at nogle af sportens ældste, ekskluderende træk bliver genkendelige dvs. eksklusionen af folk, der bruger naturen til at overleve, til fordel for dem, der bruger den til nydelse.

\section{Konklusion}

Ud fra foregående betragtninger vil jeg mene, at der er behov for en friluftslivsforskning, der kan bygge på de fagtraditioner, som beskæftiger sig med mening. Det vil ifølge sagens natur være fagområder, der fortrinsvis ligger indenfor humaniora, så som lingvistik og semiotik, etnologi og antropologi, litteratur og kunstvidenskab, historie og kulturgeografi. Det er først, når vi forstår meningen med friluftsliv, at vi kan begynde at forstå den datamasse, vi har om friluftslivslignende adfærd hos befolkningen. En lav besøgsfrekvens f.eks. kunne umiddelbart virke som et argument 
mod, at et givet område sættes til side til friluftsliv frem for til f.eks. golf, der sandsynligvis vil kunne tiltrække flere folk. Men her overser vi den mulighed, at en væsentlig del af befolkningen finder det meningsfuldt, at naturarealer friholdes til friluftslivsformål, selv om folk kun kan finde tid til at bruge dem relativt sjældent $\mathrm{i}$ deres hverdag.

Absurditeten i en konklusion, der bygger på kvantitative overvejelser alene, og dermed overser meningens betydning, kan illustreres ved et parallelt eksempel. Man kunne forestille sig en bygningsforvaltning, der opdager, at der findes en del bygninger med store sale, der stort set kun bruges en gang om ugen. Det kunne være nærliggende for sådan en forvaltning at foreslå, at disse bygninger anvendes til noget, der kunne trække flere folk til, f.eks. bowling eller folkeoplysning. Sådanne »rationelle « beslutninger kendes faktisk fra den nære fortid i Østeuropa, hvor kirker blev omdannet til brug for sådanne aktiviteter. Et afgørende træk hos et samfunds magtudøvere er deres evne til at tage alvorligt og respektere befolkningens materielle behov, såvel som vigtigheden af den mening der kommer til udtryk i immaterielle værdier. For at kunne forstå disse værdier, vis-a-vis naturen er det nødvendigt for os at lære at betragte naturen som andet og mere end fysisk materie eller vare, der skal omsættes af fritidsindustrien.

Når vi taler om meningen med noget, f.eks. livet (for ikke at tale om friluftslivet), taler vi om en overordnet hensigt, der har betydning for os som subjekter. Livets mening finder man måske i kirken, måske $\mathrm{i}$ Naturen. Fra Henry David Thoreau til Dag Hammerskjold er der i vores kultur tradition for at mene, at naturen har mening for os som subjekter. Derfor har man ofte brugt det store N. Naturen, i denne for- stand, er ikke bare er en samling fysiske objekter, som vi forholder os til som fysiske/biologiske objekter, selv når vi motionerer, o.l. Det er heller ikke en vare, som vi forbruger på linje med andre varer, der udbydes af fritidsindustrien. Selv om naturen i denne forstand kan synes at være noget alt for subjektivt til at kunne danne grundlag for forskning eller en forvaltningspraksis, er det alligevel ikke utænkeligt, at det er præcis naturens værdiladning, der har dannet baggrund for de politiske beslutninger, der har ført til det lovgrundlag, der giver rammerne for den måde, hvorpå vi i dag udøver, forsker i og forvalter friluftslivet.

Hvis man vil forstå betydningen af allemandsretten og lignende tiltag for at åbne adgangen til naturen for arbejderbevægelsen, kan man således ikke se bort fra den måde, hvorpå naturen er blevet forbundet med mere egalitære, mindre klasseopdelte samfundsformer. Derfor er det vigtigt at forske og forvalte ikke blot ud fra en bogstavelig forståelse af friluftslivets eksistensgrundlag, men også ud fra en forståelse for dets ånd eller mening. Hvis ikke vi har den forståelse, kan vi vel siges at være i den situation, som Willard V. Quine har beskrevet for lingvister:

»Pending a satisfactory explanation of the notion of meaning, linguists in the semantic field are in the situation of not knowing what they are talking about. $\ll^{13}$

Før vi er på det rene med betydningen af friluftslivets mening, ved vi med andre ord egentlig ikke, hvad det er, vi snakker om.

Artiklen er også udgivet i Lars Emmelin, (red.), Nordiskt seminarium om friluftslivsforskning, Nordiska institutet för samhällsplanering, Rapport 1994:3. 


\section{Noter}

1. Definitionerne på mening er her hentet fra Ordbog over det danske Sprog, H. Juul-Jensen (København: Gyldendal, 1919-1956). Jeg vil supplere disse definitioner med definitioner fra andre ordbøger senere i artiklen.

2. Jeg beskæftiger mig ikke med sportsgrene (herunder idræt), der har deres oprindelse i leg, f.eks. boldsport. Jeg beskæfter mig kun med sportsgrene, der kan forveksles med friluftsliv. Jeg bruger ordet sport mest i betydningen af »legemlig eller åndelig virksomhed, som man driver med særlig iver (forkærlighed), paa en (næsten) systematisk maade, vedholdende, for at kappes med andre, sætte rekord olgn.« Ordbogen over det danske Sprog.

3. Se f.eks. bogen: Natur for friluftsliv, Naturvårdsverkets årsbok 1984. (Stockholm: Naturvårdsværket, 1984).

4. Definitionerne er hentet fra henholdsvis: Webster's Seventh New Collegiate Dictionary. (Merriam: Springfield, Mass., 1963), og Ordbog over det danske Sprog.

5. Marshall Sahlins, Stone Age Economics (Chicago: University of Chicago Press, 1972); se også William Cronon's analyse i Changes in the Land: Indians, Colonists, and the Ecology of New England (New York: Hill and Wang, 1983), s. 54.81.

6. For en mere dybtgående behandling af emnet se: K.R. Olwig, »Parker, skove, kosmologier og na- turpolitik,« i Annelise Bramsnæs m.fl. (red.), Sådan ligger landet - en antologi om det åbne land. (København: Dansk Byplanlaboratorium, 1987), s. 173-91.

7. Citatet er fra: The Compact Edition of the Oxford English Dictionary (Oxford: Oxford University Press, 1971): gentleman.

8. En udredning af denne historiske udvikling findes i: Ove Korsgaard, Kampen om kroppen (København: Gyldendal, 1982).

9. Om dette emne se: Henning Eichberg og Ejgil Jespersen, De grønne bølger: Trak af natur-og friluftslivets historie (Gerlev: Bavnebanke, 1986).

10. Ingemar Ahlström, »Allemansrätten - Friluftslivets Stottepelare« i Natur för friluftsliv, Naturvårdsverkets årsbok 1984. (Stockholm: Naturvårdsværket, 1984): s. 20-24.

11.Om Seton se: K.R. Olwig, Krig og fred i naturen, Centring 7 (1986) 2: 156-169 (Temanummer om Friluftsliv og Natursyn).

12. K.R. Olwig, »Kulturvidenskabelige perspektiver på friluftslivsforskningens parodoksproblem « i Ingemar Norling, Nordisk Forskningskonferens om Friluftsliv (Göteborg: Göteborgs Universitets Institut for Social Arbejde, 1985): s. 33-45.

13. Citeret i The American Heritage Dictionary of the English Language (Boston: Houghton Miflin, 1969): meaning. 